Original Article

\title{
Indicators of full value feeding rations for dairy cows
}

\author{
Indicadores de rações de valor total para vacas leiteiras

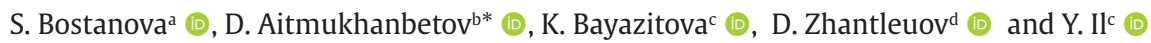 \\ ${ }^{a}$ S. Seifullin Kazakh Agro-Technical University, Department of Technology and Processing of Livestock Production, Nur-Sultan, Kazakhstan \\ 'Republican Chamber of Dairy and Combined Cattle Breeds, Nur-Sultan, Kazakhstan \\ 'M. Kozybayev North Kazakhstan University, Department of Food Security, Petropavl, Kazakhstan \\ ${ }^{\mathrm{d}}$ North Kazakhstan Research Institute of Agriculture, North Kazakhstan Region, Kyzylzhar District, Bishkul
}

\begin{abstract}
This article presents the results of the level of feeding and the health status of dairy cows in a commercial dairy farm on the content of the main components in milk (fat, protein, urea). The aim of the research was to study the milk productivity and composition of milk of cows, to analyze the level of feeding and the content of basic nutrients in the diet of the farm. The farm breeds purebred Holstein cattle with a high genetic potential for productivity. The milking herd was formed in 2009 on the basis of 600 heads of Holstein-Friesian heifers imported from Hungary, as well as 65 heads of Holsteinized heifers of Ukrainian selection from Ukraine in 2015. Today the livestock numbers about 1,500 head of cattle, of which there are about 900 breeders. On the territory of the farm there are: 3 cowsheds for keeping cows, an insemination room, a milking parlor with a parallel installation of the Delaval company, in which 48 cows are milked for one milking, the ABK, where the manager's office, livestock technician, accounting is located, and a mini-hotel with dining room and lounges. Dairy bases are equipped with auto-drinkers, ventilation, plumbing, electric lighting, manure removal mechanisms, and a milking installation. The object of the research was Holstein cows in the amount of 483 heads of Aina Dairy Farm LLP. The studies were carried out according to generally accepted zootechnical methods using modern equipment for conducting analyzes and interstate and state standards. The research results showed that the milk productivity of cows averaged $19.5 \mathrm{~kg}$ per day, the fat content $4.3 \%$, the protein $3.9 \%$, the number of somatic cells 230.5 thousand units / $\mathrm{ml}$, urea $45.3 \mathrm{mg} / 100 \mathrm{ml}$ respectively. Analyzing the level of urea in milk can suggest a high crude protein content in the diet. The ration of feeding dairy cows on the farm is concentrate-silage-haylage and there is an excess of dry matter by $16.2 \%$, crude protein by $9.8 \%$, starch by $29.4 \%$, respectively.
\end{abstract}

Keywords: milk productivity, fat, protein, feed, chemical composition, nutritional value, crude protein.

\begin{abstract}
Resumo
Este artigo apresenta os resultados do nível de alimentação e do estado de saúde de vacas leiteiras em uma fazenda comercial leiteira sobre o conteúdo dos principais componentes do leite (gordura, proteína, ureia). O objetivo da pesquisa foi estudar a produtividade e composição do leite de vacas, analisar o nível de alimentação e o teor de nutrientes básicos na dieta da fazenda. A fazenda produz gado holandês de raça pura com alto potencial genético de produtividade. $O$ rebanho leiteiro foi formado em 2009 com base em 600 cabeças de novilhas Holstein-Friesian importadas da Hungria, bem como 65 cabeças de novilhas holsteinizadas da seleção ucraniana em 2015. Hoje o gado totaliza cerca de 1.500 cabeças de gado, das quais existem cerca de 900 criadores. No território da fazenda existem: 3 estábulos para criação de vacas, uma sala de inseminação, uma sala de ordenha com instalação paralela da empresa Delaval, na qual são ordenhadas 48 vacas para cada ordenha, a ABK, onde fica o escritório do gestor, pecuária técnica, a contabilidade está localizada, e um mini-hotel com refeitório e salões. As bases leiteiras são equipadas com bebedouros automáticos, ventilação, encanamento, iluminação elétrica, mecanismo de remoção de esterco e instalação de ordenha. O objeto da pesquisa foram vacas da raça holandesa no valor de 483 cabeças da Aina Dairy Farm LLP. Os estudos foram realizados de acordo com métodos zootécnicos geralmente aceitos, utilizando equipamentos modernos para a realização de análises e padrões interestaduais e estaduais. Os resultados da pesquisa mostraram que a produtividade do leite das vacas era em média 19,5 $\mathrm{kg}$ por dia, o teor de gordura 4,3\%, a proteína 3,9\%, o número de células somáticas 230,5 mil unidades / ml, ureia 45,3 mg / $100 \mathrm{ml}$ respectivamente. A análise do nível de ureia no leite pode sugerir alto teor de proteína bruta na dieta. A ração para alimentação das vacas leiteiras na fazenda é concentrado-silagem-silagem-silagem e há excesso de matéria seca em $16,2 \%$, proteína bruta em $9,8 \%$ e amido em $29,4 \%$, respectivamente.
\end{abstract}

Palavras-chave: produtividade do leite, gordura, proteína, ração, composição química, valor nutricional, proteína bruta.

*e-mail: ssattilik@inbox.ru; kadr_90.taz@mail.ru

Received: July 9, 2021 - Accepted: July 26, 2021

This is an Open Access article distributed under the terms of the Creative Commons Attribution License, which permits unrestricted use, distribution, and reproduction in any medium, provided the original work is properly cited. 


\section{Introduction}

High milk production of dairy cows with inadequate feeding levels is the cause of many animal diseases. For example, violations of protein metabolism may occur, which leads to a decrease in milk production, a deterioration in reproduction rates, and, as a consequence, to a short life of animals. To prevent such undesirable changes, it is necessary to use various indicators, the values of which can be used to promptly adjust the parameters of feeding and maintenance (Oltner and Wiktorsson, 1983; Roseler et al., 1993). As an indicator of the level of supply of rations for dairy cows in the practice of dairy laboratories in the USA, Canada, and others, the urea content is taken, which is normally accepted in the range of $15-30 \mathrm{mg} / \%$ (Sivkin et al., 2013; Baker et al., 1995). A high content of urea increases the risk of reproductive diseases, metritis, lameness, ketosis, and liver diseases (Bolgov et al., 2019).

Earlier, indicators of the chemical composition of milk in the practice of the dairy industry of the republic were not used to control the state of homeostasis and the usefulness of animal feeding rations. The use of indicators of the content of individual milk components as indicators of the level of protein, easily digestible carbohydrates, will prevent metabolic disorders in animals, avoid the loss of their productivity. Control of the urea content in milk allows, as the experience of the dairy laboratories of the USA, Germany and others shows, to rationally use protein feeds and premixes, thereby reducing the risks of both excess and lack of crude protein in the diet of animals.

Monitoring the indicators of the composition of milk from each cow of a dairy herd will allow to diagnose metabolic disorders in advance, to start preventive measures to eliminate deviations in advance.

The use of indicators of milk composition as an indicator is also of high practical importance in the diagnosis and prevention of metabolic disorders also because it is much easier to get milk from each cow than the same blood. Collecting milk samples is a fairly standard procedure, carried out on a monthly basis during control milking, while eliminating the stress risks inherent in collecting blood samples.

The protein and carbohydrate content of the diet determines the energy supply of dairy cows. Overfeeding with protein feed in order to replenish the lack of energy can significantly worsen the indicators of protein metabolism. On the one hand, this leads to an increase in the cost of the diet, since protein feed is the most expensive feed, on the other hand, an increase in protein in the diet leads to an increase in the production of ammonia, which has a toxic effect on the animal's body. Ammonia from the cicatricial contents enters the circulatory system of ruminants, enters the liver with the bloodstream, where it is neutralized to urea. Excess urea is excreted in the urine, partially returns with saliva to the gastrointestinal tract, where it further participates in protein metabolism, and partially enters other biological fluids, including milk, where its content can serve as an indicator of the protein level in the diet. This can be confirmed by many researchers who found that the concentration of urea in milk and blood significantly depends on the intake of protein in the diet (Sivkin et al.,
2013; Baker et al., 1995; Bolgov et al., 2019). In this connection, in countries with highly developed intensive dairy cattle breeding, attempts have been made for a long time to determine reference values for the content of urea in milk and blood of animals for use as indicators of the level of protein feeding. Thus, Roseler, DK et al. Believe that the normal level of urea in the blood is $15 \mathrm{mg} / 100 \mathrm{ml}$ with fluctuations from 8 to $25 \mathrm{mg} / 100 \mathrm{ml}$, but the optimal concentration for the herd population, in their opinion, should be in the range of $12-17 \mathrm{mg} / 100 \mathrm{ml}$ (Hwang et al., 2000). Other researchers believe that the optimal level of urea in milk may be 10-14 mg / $100 \mathrm{ml}$ (Carlsson and Pehrson, 1994; Moore and Verga, 1996).

As a result, it was decided that when the values of urea in milk and blood are below the normal level, it is necessary to increase the proportion of protein broken down in the rumen, in order to replenish the nitrogen requirements of the rumen microflora for protein synthesis. The liver converts excess ammonia into urea for excretion of excess nitrogen in the urine or return to the metabolism by transferring it into the bloodstream. This is the reason for the close relationship between milk urea and blood urea (Gustafsson, and Palmquist, 1993; Jonker et al., 2002). The urea content in milk is higher than the norm, indicating that the dairy herd is consuming an excessive amount of protein, and releases excess nitrogen into the environment, thereby causing its pollution (Broderick and Clayton, 1997). An increased level of urea, as was found in one of the works, can also reduce the reproductive performance of animals (Ferguson et al., 1993; Butler et al., 1996).

Recent studies have shown that a certain level of urea concentration can be caused by an excess of rumen degradable protein with normal metabolic energy consumption, and with a normal level of rumen degradable protein, but with insufficient metabolic energy (Bolgov et al., 2019). Accordingly, the authors put forward the assumption that it is impossible to use the content of urea as an indicator without taking into account the level of consumption of metabolic energy at the same time.

One of the researchers found that the protein content in milk can reflect the level of metabolic energy consumption by lactating cows and, in this regard, it was proposed to use it as an indicator of the supply of energy to rations (Coulon and Remond, 1991; Sato, 1998). It was revealed that the protein content had a linear dependence on the level of energy supply, regardless of the stage of lactation.

Further studies confirmed the possibility of using the protein and urea content in both blood and milk to monitor the supply of protein and energy in feed (Paulicks, 1992; Hwang et al., 2000). Researchers from the National Research Institute of Dairy Farming in India have confirmed the concept of using urea and milk protein as indicators already in a dairy farm on a herd of 264 dairy cows for a year (Dhali et al., 2008).

The fat and protein content of milk can also serve as reliable indicators of both feeding levels and animal health. A high fat content with a decrease in the level of protein in milk may indicate the onset of ketosis in the body of a dairy cow, especially in the early stages of lactation, when the level of feeding does not allow to meet the energy needs of animals necessary to ensure lactation of animals. 
In this case, animals are forced to use internal fat reserves to form milk fat (Zhang et al., 2012; Duffield, 2003).

In addition to the need for constant monitoring of milk urea and milk protein, many studies show the need for constant monitoring of the level of ketone bodies in milk as the main indicator of ketosis in the animal's body (Enjalbert et al., 2001; Baticz et al., 2002; Zarrin et al., 2014; Fomenko and Serova, 2013).

In the blood, urine and milk of high-yielding cows, ketone bodies can also accumulate, which are formed as a result of ketosis of various etiologies. So, when feeding ketogenic feed (poor quality silage, moldy feed), ketone bodies are formed during the metabolism of butyric acid in the feed.

At the moment, there are about 5 million head of breeding stock of cattle in the Republic of Kazakhstan, with the average level of productivity being $2500 \mathrm{~kg}$. The average output of calves in the republic is from 46 to 78 heads per 100 heads of broodstock. These indicators indicate the problems of reproductive health on a national scale, and can lead to a complete loss of dairy cows and constant dependence on the supply of replacement animals from abroad. The reason for this decrease in the calf yield can be of various kinds, ranging from an imbalance in feed, a low level of livestock management, non-observance of artificial insemination techniques, diseases of the reproductive system and an unsatisfactory state of animal health in general. But the main problems lie in the feeding technology. An imbalance in diets for basic nutrients, an excess of protein in concentrate diets, and poor quality of basic forage entail significant disturbances in the metabolism of animals and lead to early culling of animals.

Monitoring the level of feeding and the state of metabolism will significantly save funds for the treatment of clinical diseases, preserve reproductive indicators, improve the reproduction of young animals, reduce the level of lost products and extend the terms of economic use of animals.

The research results presented in this work were carried out within the framework of grant financing of the program of the Ministry of Education and Science of the Republic of Kazakhstan under the budget program 217 "Development of Science", subprogram 102 "Grant financing of scientific research", according to the priority "Sustainable development of the agro-industrial complex and safety of agricultural products" under the project AR08956241 "Indicators of the usefulness of rations for feeding dairy cows"

The aim of the research was to study the level of milk production, the composition of milk of cows, feeding and the content of basic nutrients in the diets of the basic farm.

In the course of the research, the set goal was achieved, and the results are presented in this article.

\section{Material and Methods}

The research was carried out in LLP "Dairy farm" Aina "located in the Kenesarinsky rural district, Burabaysky district, Akmola region, 30 kilometers north of Shchuchinsk in 2020 .

The farm breeds purebred Holstein cattle with a high genetic potential for productivity. The milking herd was formed in 2009 on the basis of 600 heads of HolsteinFriesian heifers imported from Hungary, as well as 65 heads of Holsteinized heifers of Ukrainian selection from Ukraine in 2015. Today the livestock numbers about 1,500 head of cattle, of which there are about 900 breeders. On the territory of the farm there are: 3 cowsheds for keeping cows, an insemination room, a milking parlor with a parallel installation of the Delaval company, in which 48 cows are milked for one milking, the ABK, where the manager's office, livestock technician, accounting is located, and a mini-hotel with dining room and lounges. Dairy bases are equipped with auto-drinkers, ventilation, plumbing, electric lighting, manure removal mechanisms, and a milking installation. The structure of the herd in Aina Dairy Farm LLP is presented in Table 1.

According to Table 1, it can be seen that in the structure of the herd of Aina Dairy Farm LLP, the proportion of the broodstock is $60 \%$, the young stock is $34 \%$, and the fattening group is $6 \%$.

Sampling of feed was carried out in accordance with the requirements of GOST 27262-87 (1987). Sample preparation for analysis was carried out in accordance with GOST ISO 6498-2014 (2014).

Determination of dry matter was carried out by a two-stage determination method according to GOST 31640-2012 (2012). Feeds. Methods for determination of dry matter content.

Studies of the chemical composition of feed were carried out using an NIRSDS-2500 infrared analyzer manufactured by FOSS Analytical (Denmark). Indicators of the content of nitrogen-free extractives (NFE), Exchange energy and feed units were carried out by calculation method.

The content of nitrogen-free extractives was calculated by the Formula 1:

$$
N F E=1000-(C P+C F+C C F+C R A)
$$

NFE - the content of nitrogen-free extractive substances, $\mathrm{g}$ per $1 \mathrm{~kg}$;

$\mathrm{CP}$ - is the content of crude protein, $\mathrm{g}$ in $1 \mathrm{~kg}$ of dry matter; $\mathrm{CF}$ - content of crude fat, $\mathrm{g}$ in $1 \mathrm{~kg}$ of dry matter; CCF - content of crude fiber, $g$ in $1 \mathrm{~kg}$ of dry matter; CRA - the content of raw ash, $g$ in $1 \mathrm{~kg}$ of dry matter.

The calculation of the content of exchangeable energy (EE) in roughage (hay, hay cutting, haylage, straw, silage up to $50 \%$ moisture, and other roughage) was determined

Table 1. The structure of the herd in LLP "Dairy farm" Aina".

\begin{tabular}{ccccc}
\hline Breed & Livestock & Womb & Young animals & fattening \\
\hline Holstein & 1502 & 902 & 510 & 90 \\
$\%$ & 100 & 60 & 34 & 6 \\
\hline
\end{tabular}


by the Formula 2 developed by the All-Union Scientific Research Institute of Animal Husbandry:

\section{$E E=0.0212^{*} C P+0.020486^{*} C F+0.00159^{*} C C F+0.0105^{*} N F E(2)$}

NFE - the content of nitrogen-free extractive substances, g per $1 \mathrm{~kg}$;

$\mathrm{CP}$ - is the content of crude protein, $\mathrm{g}$ in $1 \mathrm{~kg}$ of dry matter; $\mathrm{CF}$ - content of crude fat, $\mathrm{g}$ in $1 \mathrm{~kg}$ of dry matter; $\mathrm{CCF}$ - content of crude fiber, $\mathrm{g}$ in $1 \mathrm{~kg}$ of dry matter;

The calculation of the content of metabolizable energy in succulent feed (root crops, high moisture silage) was determined by the Formula 3:

\section{$E E=0.0151^{*} \mathrm{CP}+0.01378^{*} \mathrm{CF}+0.00328^{*} \mathrm{CCF}+0.01265^{*} \mathrm{NFE}$}

The calculation of the content of metabolizable energy in concentrated feed (grain of cereals and legumes, turf, flour) was determined by the Formula 4 :

$$
E E=0.02085^{*} \mathrm{CP}+0.01715^{*} \mathrm{CF}-0.001865^{*} \mathrm{CCF}+0.01226^{*} \mathrm{NFE}
$$

The calculation of the content of exchangeable energy in the technical waste of the processing industry (oilcakes, meal, grains, grains, dry root crops, bran, etc.) was determined according to GOST R 53900-2010 (2010) according to the Formula 5:

\section{$\mathrm{EE}=0.02157^{*} \mathrm{CP}+0.01667^{*} \mathrm{CF}-0.003772^{*} \mathrm{CCF}+0.01074^{*} \mathrm{NFE}(5)$}

Milk sampling was carried out in accordance with the requirements of ST RK ISO 707-2011 (2011, ISO 707: 2008, IDT) Milk and dairy products. Sampling Guide.

The study of the chemical composition of milk was carried out in the laboratory.

Testing center LLP "Kazakh Research Institute of Livestock and Forage Production" on the CombiFossFT + milk analyzer manufactured by FOSS Analytical (Denmark) in accordance with GOST 32255-2013 (2013).

When carrying out work on the analysis of the chemical composition of milk, the chemical composition and nutritional value of feed, the corresponding interstate and state standards were used.

\section{Results and Discussion}

Milk productivity and milk composition were determined in the dairy farm on the basis of monthly control milking data, where milk samples were taken from 483 dairy cows. The results of chemical analysis and daily milk yield are shown in Table 2 .

According to Table 2, it can be seen that the indicators of milk productivity of the dairy herd of LLP "Dairy farm"
Aina "are characteristic of the Holstein breed standard. The management of the herd, judging by the content of fat and protein, their ratio and the content of somatic cells, is carried out at a fairly high level. However, a high urea content in milk can signal a high crude protein content in the diet. Table 3 shows the analysis of the ratio of fat and protein in the milk of dairy cows of the basic farm.

Based on the experience of the dairy laboratories in the USA and Canada, it can be said that the overall health of the herd is within the normal range. However, the ranking of the herd according to this indicator shows a tendency for this ratio to shift towards less than 1.1: 1, which often occurs with a diet rich in energy and poor structure (concentrate type of feeding). In this case, it is necessary to correctly distribute the compound feed in accordance with the productivity.

When interpreting the ratio of fat to protein in the first third of lactation, one should take into account that both the threat of ketosis (with a high rate) (Duffield, 2000) and the threat of rumen acidosis (with a low rate) (Kleen et al., 2003) are possible.

The risks of acidosis are also confirmed by the data in Table 4 - all dairy cattle of the basic farm have urea in milk above the threshold value determined at $30 \mathrm{mg} / 100 \mathrm{ml}$ (Gustafsson and Palmquist, 1993), according to the adopted standard in Western Europe, North America and etc. This picture is due to a greater extent to the concentrate type of feeding, and, accordingly, the high content of crude protein in the diet of dairy cows.

An important indicator of the health of the udder of lactating animals is the content of somatic cells in milk, the counting results of which are shown in Table 5.

According to the table, it can be generally said that the situation in the dairy herd of Aina Dairy Farm LLP in terms of the incidence of mastitis is generally favorable: the share of conventionally healthy animals in general exceeds $95 \%$, the number of subclinically sick animals is about $2.5 \%$, clinically sick $-1.7 \%$. The average content of somatic cells in the milk of a dairy herd is 230.5 cells per milliliter.

According to the data of daily milk yield and the content of the main components of milk, a correlation analysis was carried out, the results of which are shown in Table 6.

As can be seen from the data in the table, a generally accepted picture is observed in the dairy herd of Aina Dairy Farm LLP: there is a weak negative relationship at the level of -0.1 between the level of milk yield and the content of protein and fat in milk, and there is a slight positive relationship between butterfat and milk protein.

Table 2. The chemical composition of milk and the content of somatic cells in the milk of dairy cows LLP "Dairy farm" Aina".

\begin{tabular}{ccccccc}
\hline Indicator & $\begin{array}{c}\text { Daily milk yield, } \\
\text { kg/ head }\end{array}$ & Fat\% & Protein\% & fat / protein & $\begin{array}{c}\text { The number of } \\
\text { somatic cells, } \\
\text { thousand units / ml }\end{array}$ & $\begin{array}{c}\text { Urea, } \\
\mathbf{M g} / \mathbf{1 0 0} \\
\mathbf{~ m l}\end{array}$ \\
\hline Average & 19.5 & 4.3 & 3.9 & 1.1 & 230.5 & 45.3 \\
Maximum & 44.8 & 6.0 & 5.0 & 1.9 & 2422.0 & 61.6 \\
Minimum & 3.1 & 2.6 & 3.0 & 0.6 & 11.0 & 31.8 \\
\hline
\end{tabular}


Table 3. Ratios of fat and protein in milk of dairy cows of the basic farm.

\begin{tabular}{ccc}
\hline fat / protein & $\begin{array}{c}\text { Number of cows in } \\
\text { the current month }\end{array}$ & $\begin{array}{c}\text { As a percentage } \\
\text { of livestock,\% }\end{array}$ \\
\hline 1.5 and more & 37 & 7.7 \\
$1,1-1,5$ & 210.00 & 43.5 \\
Less than 1.1 & 236 & 48.9 \\
Total & 483 & 100 \\
\hline
\end{tabular}

Table 4. The content of urea in milk of a dairy herd.

\begin{tabular}{ccc}
\hline $\begin{array}{c}\text { Urea content in } \\
\text { milk, } \\
\mathbf{~ m g} / \mathbf{1 0 0} \mathbf{~ m l}\end{array}$ & $\begin{array}{c}\text { Number of cows in } \\
\text { the current month }\end{array}$ & $\begin{array}{c}\text { As a percentage } \\
\text { of livestock,\% }\end{array}$ \\
\hline 30 and more & 483 & 100.0 \\
$15-30$ & 0 & 0.0 \\
Less than 15 & 0 & 0.0 \\
Total & 483 & 100 \\
\hline
\end{tabular}

Table 5. Analysis of the number of somatic cells in the milk of dairy cows LLP "Dairy farm" Aina".

\begin{tabular}{ccc}
\hline $\begin{array}{c}\text { The number of } \\
\text { somatic cells, } \\
\text { thousand } / \mathbf{m l}\end{array}$ & $\begin{array}{c}\text { Number of cows } \\
\text { in the current } \\
\text { month }\end{array}$ & $\begin{array}{c}\text { As a } \\
\text { percentage of } \\
\text { livestock,\% }\end{array}$ \\
\hline $0-200$ & 300 & 62.1 \\
$200-500$ & 163.00 & 33.7 \\
$501-1000$ & 12.00 & 2.5 \\
1001 and more & 8 & 1.7 \\
Total & 483 & 100 \\
\hline
\end{tabular}

Table 6. The relationship between the daily milk yield and the content of the main components of milk.

\begin{tabular}{ccccc}
\hline Indicator & $\begin{array}{c}\text { Daily } \\
\text { milk } \\
\text { yield, } \\
\mathbf{~ k g}\end{array}$ & Fat,\% & Protein,\% & $\begin{array}{c}\text { Urea, } \\
\mathbf{m g} /\end{array}$ \\
$\mathbf{1 0 0} \mathbf{g}$ \\
\hline $\begin{array}{c}\text { Daily milk } \\
\text { yield, kg }\end{array}$ & +1 & - & - & - \\
Fat,\% & -0.1 & +1.0 & - & - \\
Protein,\% & -0.1 & +0.05 & +1.0 & - \\
$\begin{array}{c}\text { Urea, mg / } \\
100 \mathrm{~g}\end{array}$ & -0.002 & +0.04 & +0.1 & +1.0 \\
\hline
\end{tabular}

There is practically no connection between the urea content and the milk yield (-0.002), which gives reason to believe that the supply of raw protein and metabolic energy in the diets is more influenced by the content of urea in milk.
The analysis of individual milk samples taken from the dairy herd of Aina Dairy Farm LLP shows that the content of the main components of milk is within the physiological norm. However, ranking the flock by fat / protein ratio tends to bias this ratio towards less than 1.1: 1 , which often occurs with a diet rich in energy and poor structure (concentrate feeding). A fat / protein ratio of less than 1 may indicate a threat of rumen acidosis (if the value is low).

To normalize the feeding of a dairy herd, it is necessary to increase the proportion of coarse and succulent feed in the diet and to improve the quality of the main feed silage and haylage, by observing the technology of laying raw materials in trenches, the timing of harvesting green mass, using the appropriate varieties and hybrids capable of growing in a short growing season. period.

For the full realization of the genetic potential of livestock dairy productivity, it is necessary, first of all, to have a complete balanced feeding. Highly productive animals need quality feeding, otherwise they will not be able to give the amount of milk that can be obtained from them. Therefore, the problem of feeding dairy cattle in dairy farms is one of the most urgent (Khokhrin, 2003). The farm is fully self-sufficient in feed, but part of the feed, primarily premixes and concentrated protein feeds such as soybean and rapeseed meal are purchased. Zootechnical analysis of the chemical composition and nutritional value of the feed was carried out according to the classical Veende scheme. The results of the study of the chemical composition and nutritional value of the main forages of LLP "Dairy farm" Aina "are shown in Table 7.

Table 8 shows the ration for feeding dairy cows at the 2nd stage of lactation with a live weight of $640 \mathrm{~kg}$, an average daily milk yield of $25 \mathrm{~kg}$, a milk fat content of $3.8 \%$. The rationing of the diet for the content of nutrients and nutritional value was carried out according to the norms and rations for feeding farm animals (Kalashnikov et al., 2003).

The study of rations for feeding dairy cows LLP "Dairy farm" Aina "showed that concentrate-silage-haylage type of feeding is used. The diet basically meets all of the animal's nutritional and energy needs.

As can be seen from the data in Table 8, the ration contains an excess of dry matter by $16.2 \%$, crude protein by $9.8 \%$, and starch by $29.4 \%$. Conversely, the sugar content is deficient: $-72.9 \%$. Thus, it can be noted that the feeding ration on the farm is typical for the majority of dairy farms in our republic with a predominance of concentrated feed in terms of nutritional value (about 50\%). To balance this type of ration, it is necessary to improve the quality of the main feed, namely silage and haylage. Silage quality remains poor. For the future, it is necessary to recommend the farm to harvest higher quality silage, with a dry matter content of at least $40 \%$.

In dairy cattle breeding, a clear organization of systematic control of the level of milk production, the completeness of feeding, the state of metabolism in the body of animals and the quality of products is necessary.

Control of the usefulness of the rations is carried out by zootechnical and veterinary-biochemical methods. The main methods of control over the completeness of animal feeding are: analysis of the quality of feed, balance 
Table 7. Chemical composition and nutritional value of basic feeds per $1 \mathrm{~kg}$ of dry matter.

\begin{tabular}{|c|c|c|c|c|c|c|c|c|c|}
\hline $\begin{array}{c}\text { Name of } \\
\text { feed }\end{array}$ & $\begin{array}{c}\text { Dry } \\
\text { matter,\% }\end{array}$ & $\begin{array}{c}\text { Crude } \\
\text { protein, } \\
\quad \mathbf{g}\end{array}$ & $\begin{array}{l}\text { Crude } \\
\text { fat, } g\end{array}$ & $\begin{array}{c}\text { Crude } \\
\text { fiber, } g\end{array}$ & $\begin{array}{l}\text { Crude } \\
\text { ash, g }\end{array}$ & $\begin{array}{c}\text { Starch, } \\
\text { g }\end{array}$ & NFE,g & Feed units & $\begin{array}{c}\text { Metabolic } \\
\text { energy } \\
\text { of cattle, } \\
\text { Megajoule } \\
\text { (MJ)/ kg dry } \\
\text { matter (DM) }\end{array}$ \\
\hline Wheat & 79.74 & 125.20 & 22.33 & 28.31 & 17.54 & 436.76 & 604.07 & 1.11 & 10.45 \\
\hline Silage & 37.69 & 31.66 & 15.83 & 137.07 & 28.72 & 12.59 & 163.60 & 0.09 & 2.00 \\
\hline Haylage & 42.05 & 34.90 & 20.18 & 151.34 & 33.72 & 38.77 & 180.35 & 0.18 & 3.09 \\
\hline Hay & 88.66 & 61.17 & 23.94 & 285.74 & 70.66 & 27.48 & 445.06 & 0.44 & 6.91 \\
\hline Barda dry & 90.47 & 301.25 & 34.38 & 114.71 & 45.41 & 124.30 & 408.91 & 1.31 & 12.10 \\
\hline $\begin{array}{c}\text { Soybean } \\
\text { meal }\end{array}$ & 85.18 & 347.54 & 0.00 & 61.59 & 62.27 & 2.56 & 380.43 & 1.38 & 12.03 \\
\hline
\end{tabular}

Table 8. Diet for feeding dairy cows with a live weight of $600 \mathrm{~kg}$ and a productivity of $25 \mathrm{~kg}$ of milk per day, milk fat content $3.8 \%$.

\begin{tabular}{|c|c|c|c|c|c|c|c|c|c|c|c|}
\hline Name of feed & $\begin{array}{c}\text { Daily } \\
\text { rate, } \mathrm{kg}\end{array}$ & $\begin{array}{c}\text { Dry } \\
\text { matter, } \\
\text { kg }\end{array}$ & $\begin{array}{c}\text { Crude } \\
\text { protein, } \mathrm{g}\end{array}$ & $\begin{array}{l}\text { Crude } \\
\text { fat, } g\end{array}$ & $\begin{array}{c}\text { Crude } \\
\text { fiber, } g\end{array}$ & $\begin{array}{l}\text { Crude } \\
\text { ash, g }\end{array}$ & $\begin{array}{c}\text { Starch, } \\
\text { g }\end{array}$ & Sugar, $\mathrm{g}$ & NFE,g & $\begin{array}{l}\text { Feed } \\
\text { units }\end{array}$ & $\begin{array}{c}\text { Metabolic } \\
\text { energy } \\
\text { of cattle, } \\
\text { Megajoule (MJ) } \\
\text { / kg dry matter } \\
\text { DM }\end{array}$ \\
\hline $\begin{array}{l}\text { Grain mixture } \\
\text { (wheat }+ \\
\text { barley) }\end{array}$ & 7.00 & 4.3 & 676.1 & 120.6 & 152.9 & 94.7 & 2358.5 & 108.0 & 3262.0 & 6.0 & 56.4 \\
\hline Soybean meal & 2.60 & 2.2 & 903.6 & 0.0 & 160.1 & 161.9 & 6.6 & 126.4 & 989.1 & 3.6 & 31.3 \\
\hline Haylage & 16.00 & 6.7 & 558.4 & 322.9 & 2421.4 & 539.6 & 620.3 & 136.0 & 2877.6 & 3.3 & 52.5 \\
\hline Silage & 16.00 & 5.9 & 506.5 & 253.3 & 2193.2 & 459.5 & 201.4 & 96.0 & 2507.6 & 3.4 & 50.1 \\
\hline Hay & 2.00 & 1.8 & 122.3 & 47.9 & 571.5 & 141.3 & 55.0 & 18.0 & 890.1 & 0.9 & 13.8 \\
\hline Barda dry & 2.00 & 1.8 & 602.5 & 68.8 & 229.4 & 90.8 & 248.6 & 0.0 & 817.8 & 2.6 & 24.2 \\
\hline $\begin{array}{c}\text { Total in the } \\
\text { diet }\end{array}$ & 45.60 & 22.7 & 3369.5 & 3.4 & 5728.5 & 1487.9 & 3490.5 & 484.4 & 11344.2 & 19.8 & 228.3 \\
\hline norm & & 19.6 & 3069.1 & & 3985.0 & & 2696.7 & 1785.4 & & 20.3 & 230.6 \\
\hline $\begin{array}{l}\text { Deviation } \\
\text { from the } \\
\text { norm,\% }\end{array}$ & & +16.2 & +9.8 & & +43.8 & & +29.4 & -72.9 & & -2.3 & -1.0 \\
\hline
\end{tabular}

of diets, the state of metabolism; study of body responses, biochemical parameters of blood, urine, milk, etc.

Aina Dairy Farm LLP, where the research was carried out, has a sufficient amount of natural forage lands to comply with the technological conditions for feeding and keeping highly productive cows.

In the dairy herd of Aina Dairy Farm LLP, a generally accepted picture is observed: between the level of milk yield and the content of protein and fat in milk, there is a weak negative relationship at the level of - 0.1 , and there is a slight positive relationship between fat and milk content.

There is practically no connection between the urea content and the milk yield (-0.002), which gives reason to believe that the supply of raw protein and metabolic energy in the diets is more influenced by the content of urea in milk.

The analysis of individual milk samples taken from the dairy herd of Aina Dairy Farm LLP shows that the content of the main components of milk is within the physiological norm. However, ranking the flock by fat / protein ratio tends to bias this ratio towards less than 1.1: 1 , which often occurs with a diet rich in energy and poor structure (concentrate feeding). A fat / protein ratio of less than 1 may indicate a threat of rumen acidosis (if the value is low). Risks of acidosis are also supported by the data in Table 5 - the urea content in milk is above the threshold defined at $30 \mathrm{mg} / 100 \mathrm{ml}$, and is caused by the high content of crude protein in the diet of dairy cows. 
Research by (Filinskaya and Kevorkyan, 2018) to control the nutritional value of highly productive cows, carried out on a Holstein breed with a daily milk yield of $46 \mathrm{~kg}$ at 000 Plemzavod Rodina, showed that the content of crude protein was $18.66 \%$, the energy concentration was 11.6 MJ, which is close to normal, the total amount of fiber in the analyzed ration of the farm is below the norm (is $13.34 \%$ ) and the content of NDK, FDC in the dry matter of the ration does not exceed the recommended values. Nevertheless, thanks to the organization of full-fledged feeding of cows, a regular comprehensive assessment of the efficiency of feed intake and digestibility, along with other organizational solutions, the Rodina breeding plant LLC achieved high indicators of cow productivity (average annual milk yield per cow in 2017 - 12,216 kg).

Similar studies were obtained by (Papusha, 2018) carried out on black-and-white cows of the brood herd of Viktorovskoye LLP, Kostanay region, to study urea in milk as an indicator of the usefulness of feeding cows. The results of the work showed that $44.1 \%$ of cows in the studied herd are unproductively using feed protein, protein conversion is inefficient, which leads to overconsumption of concentrated feed, a decrease in the level of urea in milk (below $15 \mathrm{mg} / \%$ ) leads to a decrease in reproductive functions and productivity of cows per $1085.7 \mathrm{~kg}$ of milk, or $17.4 \%$ of the average productivity of the herd, firstheifers and cows that are 6 months of lactation, in which an increased content of urea in milk (more than $30 \mathrm{mg} / \%$ ) is detected, it is necessary to adjust the diet and provide a balanced diet.

In further studies, it is necessary to establish the influence of different levels of crude protein on the content of urea in milk, to establish the optimal parameters of urea in milk and crude protein in feeding rations.

\section{Conclusions}

1. The analysis of individual milk samples taken from the dairy herd of Aina Dairy Farm LLP shows that the content of the main components of milk is within the physiological norm. However, ranking the flock by fat / protein ratio tends to bias this ratio towards less than 1.1: 1 , which often occurs with a diet rich in energy and poor structure (concentrate feeding). A fat / protein ratio of less than 1 may indicate a threat of rumen acidosis (if the value is low);

2. The study of the rations of feeding dairy cows LLP "Dairy farm" Aina "showed that the concentrate-silage-haylage type of feeding is used. The diet basically meets all of the animal's nutritional and energy needs;

3. The ration contains an excess of dry matter by $16.2 \%$, crude protein by $9.8 \%$, starch by $29.4 .1 \%$. The sugar content, on the contrary, is in short supply: $-72.9 \%$, the feeding ration on the farm is typical for the majority of dairy farms in our republic with a predominance of concentrated feed in terms of nutritional value (about $50 \%)$;

4. To normalize the feeding of a dairy herd, it is necessary to increase the proportion of coarse and succulent feed in the diet and to improve the quality of the main feed
- silage and haylage, by observing the technology of laying raw materials in trenches, the timing of harvesting green mass, using the appropriate varieties and hybrids capable of growing in a short the growing season;

5. The use of milk indicators as indicators of the completeness of feeding is quite justified, since already at the initial stage of research, the influence of the level of crude protein on the content of urea in milk was established, as well as a shift in the fat / protein ratio of less than 1.1: 1 with a high proportion of concentrated feed in diet.

\section{Acknowledgements}

The research results presented in this work were carried out within the framework of grant financing of the program of the Ministry of Education and Science of the Republic of Kazakhstan under the budget program 217 "Development of Science", subprogram 102 "Grant financing of scientific research", according to the priority "Sustainable development of the agro-industrial complex and safety of agricultural products" under the project AR08956241 "Indicators of the usefulness of rations for feeding dairy cows”.

\section{References}

BAKER, L.D., FERGUSON, J.D. and CHALUPA, W., 1995. Responses in urea and true protein of milk to different protein feeding schemes for dairy cows. Journal of Dairy Science, vol. 78, no. 11, pp. 2424-2434. http://dx.doi.org/10.3168/jds.S00220302(95)76871-0. PMid:8747334.

BATICZ, O., TÖMÖSKÖZI, S. and VIDA, L., 2002. Concentrations of citrate and ketone bodies in cow's raw milk. Periodica Polytechnica Chemical Engineering, vol. 46, no. 1, pp. 93-104.

BOLGOV, A.E., KOMLYK, I.P. and GRISHINA, N.V., 2019. Variability and relationship of food and indicator indicators of milk of Ayrshire cows. Izvestiya SPbGAU, vol. 1, no. 54, pp. 115-122.

BRODERICK, G.A. and CLAYTON, M.C., 1997. A statistical evaluation of animal and nutritional factors influencing concentrations of milk urea nitrogen. Journal of Dairy Science, vol. 80, no. 11, pp. 2424-2434. http://dx.doi.org/10.3168/jds.S00220302(97)76262-3. PMid:9406089.

BUTLER, W.R., CALAMAN, J.J. and BEAM, S.W., 1996. Plasma and milk urea nitrogen in relation to pregnancy rate in lactating dairy cattle. Journal of Animal Science, vol. 74, no. 4, pp. 858865. http://dx.doi.org/10.2527/1996.744858x. PMid:8728008.

CARLSSON, J. and PEHRSON, B., 1994. The influence of dietary balance between energy and protein on milk urea concentration. Experimental trials assessed by two different protein evaluation systems. Acta Veterinaria Scandinavica, vol. 35, no. 2, pp. 193205. http://dx.doi.org/10.1186/BF03548347. PMid:7942385.

COULON, J.B. and REMOND, B., 1991. Variations in milk output and milk protein content in response to the level of energy supply to the dairy cows: a review. Livestock Production Science, vol. 29, no. 1, pp. 31-47. http://dx.doi.org/10.1016/0301-6226(91)90118-A.

DHALI, A., MEHLA, R.K., SIROHI, S.K., MECH, A. and KARUNAKARAN, M., 2008. Monitoring feeding adequacy in dairy cows using milk urea and milk protein contents under farm condition. Asian-Australasian Journal of Animal Sciences, vol. 19, no. 12, pp. 1742-1748. 
DUFFIELD, T., 2000. Subclinical ketosis in lactating dairy cattle. The Veterinary Clinics of North America. Food Animal Practice, vol. 16, no. 2, pp. 231-253. http://dx.doi.org/10.1016/S07490720(15)30103-1. PMid:11022338.

DUFFIELD, T., 2003. Minimizing subclinical metabolic diseases. Tri-State Dairy Nutrition Conference, vol. 26, pp. 1-14.

ENJALBERT, F., NICOT, M.C., BAYOURTHE, C. and MONCOULON, R., 2001. Ketone bodies in milk and blood of dairy cows: relationship between concentrations and utilization for detection of subclinical ketosis. Journal of Dairy Science, vol. 84, no. 3, pp. 583-589. http://dx.doi.org/10.3168/jds.S00220302(01)74511-0. PMid:11286410.

FERGUSON, J.D., GALLIGAN, D.T., BLANCHARD, T. and REEVES, M., 1993. Serum urea nitrogen and conception rate: the usefulness of test information. Journal of Dairy Science, vol. 76, no. 12, pp. 3742-3746. http://dx.doi.org/10.3168/jds.S0022-0302(93)777164. PMid:8132880.

FILINSKAYA, O.V., and KEVORKYAN, S.A., 2018. Practical methods for monitoring the nutritional value of highly productive cows in a modern complex. Biotechnology, selection, reproduction. Bulletin of the Agro-industrial Complex Upper Volga, vol. 4, no. 44, pp. 30-36.

FOMENKO, P.A. and SEROVA, S.V., 2013. Analysis of the influence of diets on the biochemical parameters of blood. Dairy Bulletin, vol. 4, no. 12, pp. 229-236.

GOST 27262-87, 1987. INTERSTATE STANDARD. Vegetable feeds. Sampling methods. Moscow: Publishing House of Standards. Available from: https://docs.cntd.ru/document/1200024371.

GOST 31640-2012, 2012. Feeds. Methods for determination of dry matter content. Moscow: Publishing House of Standards. Available from: https://docs.cntd.ru/document/1200095394.

GOST 32255-2013, 2013. Milk and milk products. Instrumental express-method for determination of physic-chemical identification parameters by infrared analyzer. Moscow: Publishing House of Standards. Available from: https://docs.cntd.ru/ document/1200107352.

GOST ISO 6498-2014, 2014. Feeds, compound feeds. Preparation of samples for testing. Moscow: Publishing House of Standards. Available from: https://docs.cntd.ru/document/1200114284.

GOST R 53900-2010, 2010. Feed barley. Specifications. Moscow: Publishing House of Standards. Available from: https://docs. cntd.ru/document/1200082179.

GUSTAFSSON, A.H. and PALMQUIST, D.L., 1993. Diurnal variation of rumen ammonia, serum urea and milk urea in dairy cows at high and low yields. Journal of Dairy Science, vol. 76, no. 2, pp. 475-484. http://dx.doi.org/10.3168/jds.S0022-0302(93)773683. PMid: 8445100 .

HWANG, S.Y., LEE, M.J. and CHIOU, P.W., 2000. Monitoring nutritional status of dairy cows in Taiwan using milk protein and milk urea nitrogen. Asian-Australasian Journal of Animal Sciences, vol. 13, no. 12 , pp. 1667-1673.
JONKER, J.S., KOHN, R.A. and HIGH, J.. 2002. Use of milk urea nitrogen to improve dairy cow diets. Journal of Dairy Science, vol. 86, no. 4, pp. 939-946. http://dx.doi.org/10.3168/jds.S00220302(02)74152-0. PMid:12018439.

KALASHNIKOV, A.P., FISININ, V.I., SHCHEGLOVA, V.V. and KLEIMENOVA, N.I., 2003. Rates and rations for feeding farm animals. Reference manual. 3rd ed. Moscow: Russian Agricultural Academy.

KHOKHRIN, S.N., 2002. Animal feed and feeding. St. Petersburg: Lan.

KLEEN, J.L., HOOIJER, G.A., REHAGE, J. and NOORDHUIZEN, J.P., 2003. Subacute ruminal acodosis (SARA): a review. Journal of Veterinary Medicine Series A: Physiology, Pathology, Clinical Medicine, vol. 50, no. 8, pp. 406-414.

MOORE, D.A. and VERGA, G., 1996. BUN and MUN: urea nitrogen testing in dairy cattle. The Compendium on continuing education for the practicing veterinarian (USA), vol. 18, pp. 712-721.

OLTNER, R. and WIKTORSSON, H., 1983. Urea concentrations in milk and blood as influenced by feeding varying amounts of protein and energy to dairy cows. Livestock Production Science, vol. 10, no. 5, pp. 457-467. http://dx.doi.org/10.1016/03016226(83)90073-8.

PAPUSHA, N.V., 2018. Milk urea as an indicator of the usefulness of feeding black-and-white cows. International Research Journal. Agricultural Sciences, vol. 7, no. 73, pp. 76-79.

PAULICKS, B., 1992. When is the urea test useful. Tierzüchter., vol. 44, pp. 36-38.

ROSELER, D.K., FERGUSON, J.D., SNIFFEN, C.J. and HERREMA, J., 1993. Dietary protein degradability effects on plasma and milk urea nitrogen and milk nonprotein nitrogen in Holstein cows. Journal of Dairy Science, vol. 76, no. 2, pp. 525-534. http:// dx.doi.org/10.3168/jds.S0022-0302(93)77372-5.

SATO, H., 1998. Correlations between milk urea and plasma metabolites and milk fat and protein concentrations in dairy cows. Nippon Juishikai Zasshi, vol. 51, no. 5, pp. 242-245. http:// dx.doi.org/10.12935/jvma1951.51.242.

SIVKIN, N.V., KARPOV, A.P., GLADYR, E.A. and GUSEV, I.V., 2013. The composition of milk in assessing the usefulness of feeding new-calf black-and-white cows. Achievements of Science and Technology of the Agro-industrial Complex, vol. 3, pp. 58-64.

ST RK ISO 707-2011 (ISO 707: 2008, IDT), 2011. Milk and dairy products. Sampling Guide. Moscow: Publishing House of Standards. Available from: https://online.zakon.kz/ Document/?doc_id=31408334.

ZARRIN, M., DE MATTEIS, L., VERNAY, M.C., WELLNITZ, O., VAN DORLAND, H.A. and BRUCKMAIER, R.M., 2014. Long-term elevation of $\beta$-hydroxybutyrate in dairy through infusion: effects on feed intake, milk production, and metabolism. Journal of Dairy Science, vol. 96, no. 5, pp. 2960-2972. http://dx.doi. org/10.3168/jds.2012-6224. PMid:23498021.

ZHANG, Z., LIU, G., WANG, H., LI, X., and WANG, Z., 2012. Detection of subclinical ketosisin dairy cows. Pakistan Veterinary Journal, vol. 32, no. 2, pp. 156-160. 